\title{
PET/CT imaging of metastatic Merkel cell carcinoma to the adrenal glands
}

\author{
G Greene, ${ }^{1}$ I Mezheritskiy, ${ }^{2}$ D M Biko ${ }^{3}$ \\ ${ }^{1}$ Department of Radiology \& Nuclear Medicine, Pennsylvania Hospital, University of Penn Health System, Philadelphia, Pennsylvania, USA \\ ${ }^{2}$ Department of Radiology, Pennsylvania Hospital, Philadelphia, Pennsylvania, USA \\ ${ }^{3}$ Department of Radiology, Children's Hospital of Philadelphia, Philadelphia, Pennsylvania, USA
}

Correspondence to Gary Greene, greeneg@pahosp.com

\section{DESCRIPTION}

A positron emission tomography (PET)/CT examination performed on an elderly man, known to have Merkel cell carcinoma (MCC) resected 3 years earlier, showed abnormal fludeoxyglucose 18F (FDG) uptake within new masses in the right and left adrenal gland with standard uptake value (SUV) measurements of 6.4 and 9.3, respectively, which histologically represented metastatic MCC (figure 1).

MCC is a rare neuroendocrine tumour of the cells of the basal layers of the epidermi. ${ }^{1}$ The main risk factor is exposure to sunlight and ultraviolet light. Most patients $(70-80 \%)$ present with localised disease. Even with local excision, the incidence of distant metastatic disease (18-52\%), regional nodal metastases (45-91\%) and local recurrence $(27-60 \%)$ are high and usually occur within 2 years of the diagnosis. Besides local and recurrent lymph nodes, metastatic disease has been reported in the adrenal gland, liver, mediastinum, peritoneum, lung and subcutane- ous fat. There is no agreed upon imaging modality for evaluation of MCC although nuclear imaging modalities using lymphoscintigraphy for evaluation of sentinel nodes and somatostatin receptor scintigraphy for evaluation of local and distant metastases and recurrence have been used. There has also been an increasing role of PET/CT in evaluating MCC. PET has been shown to detect occult disease that was not detected by physical examination, CT or somatostatin receptor scintigraphy. ${ }^{2} 3$

Competing interests None.

Patient consent Not obtained.

\section{REFERENCES}

1. Pectasides D, Pectasides M, Economopoulos T. Merkel cell cancer of the skin. Ann Oncol 2006;17:1489-95.

2. Gollub MJ, Gruen DR, Dershaw DD. Merkel cell carcinoma: CT findings in 12 patients. AJR Am J Roentgenol 1996;167:617-20.

3. Nguyen BD, McCullough AE. Imaging of Merkel cell carcinoma. Radiographics 2002;22:367-76.

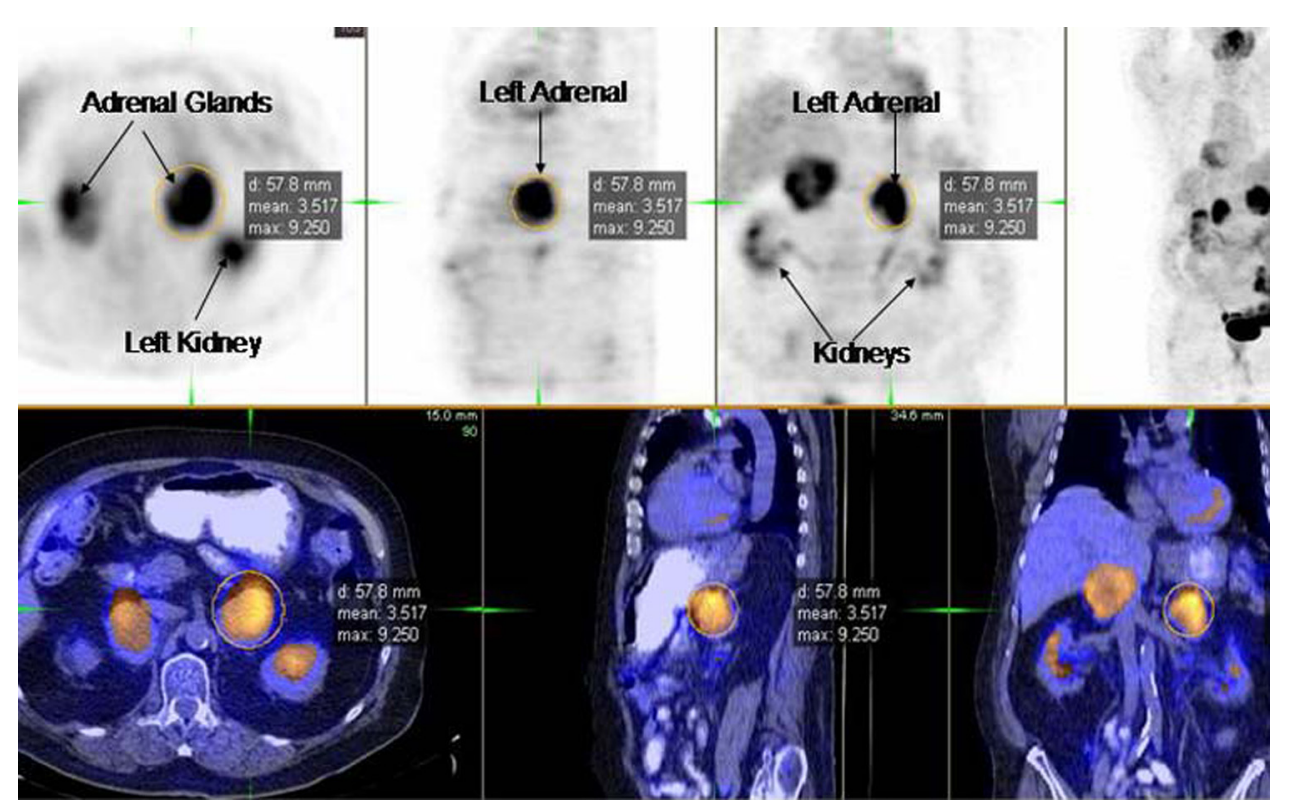

Figure 1 Positron emission tomography (PET) images (upper row) in the axial, sagittal and coronal cuts (left to right) demonstrate focal increased metabolism within both adrenal glands (arrows) consistent with metabolically active tumour. Physiological uptake is noted in the left kidney (lower arrow). Regions of interest project on all images as an orange circle. Fused PET/CT images (bottom row) demonstrate abnormal adrenal uptake. Left adrenal mass reveals a standard uptake value of 9.25 , which is consistent with malignancy. 


\section{BMJ Case Reports}

This pdf has been created automatically from the final edited text and images.

Copyright 2010 BMJ Publishing Group. All rights reserved. For permission to reuse any of this content visit http://group.bmj.com/group/rights-licensing/permissions.

BMJ Case Report Fellows may re-use this article for personal use and teaching without any further permission.

Please cite this article as follows (you will need to access the article online to obtain the date of publication).

Greene G, Mezheritskiy I, Biko DM. PET/CT imaging of metastatic Merkel cell carcinoma to the adrenal glands. BMJ Case Reports 2010;

10.1136/bcr.03.2010.2788, date of publication

Become a Fellow of BMJ Case Reports today and you can:

Submit as many cases as you like

Enjoy fast sympathetic peer review and rapid publication of accepted articles

Access all the published articles

Re-use any of the published material for personal use and teaching without further permission

For information on Institutional Fellowships contact consortiasales@bmjgroup.com

Visit casereports.bmj.com for more articles like this and to become a Fellow 